\title{
Peningkatan Mutu Sekolah dengan Meningkatkan Kinerja Guru Melalui Pelatihan Berkelanjutan di SDN Lanta Barat Tahun Pelajaran 2019-2020
}

\author{
Syarifuddin \\ SDN Lanta Barat \\ syarifuddin_sdnlantabarat71@gmail.com
}

\begin{abstract}
Dalam pendidikan, mutu adalah suatu keberhasilan proses belajar yang menyenangkan dan memberikan kenikmatan. Pelanggan bisa berupa mereka yang langsung menjadi penerima produk dan jasa tersebut atau mereka yang nantinya akan merasakan manfaat produk dan jasa tersebut. Penelitian ini bertujuan untuk peningkatan mutu sekolah di SDN Lanta Barat dengan meningkatkan Kinerja Guru Melalui Pelatihan Berkelanjutan Tahun Pelajaran 2019-2020. Jenis ini adalah Penelitian Tindakan sekolah, Desain Penelitian Tindakan Sekolah yang digunakan sesuai dengan model PTS Arikunto. Setiap siklus meliputi perencanaan, tindakan, pengamatan, evaluasi serta refleksi. Subyek dalam penelitian ini adalah guru SDN Lanta Barat Tahun Pelajaran 2019/2020 sebanyak 15 orang. Instrumen yang digunakan dalam penelitian ini adalah lembar observasi dan Angket. Berdasarkan hasil analisis data dan pembahasan yang telah dilakukan dapat disimpulkan bahwa: ada peningkatan mutu sekolah di SDN Lanta Barat dengan meningkatkan Kinerja Guru Melalui Pelatihan Berkelanjutan Tahun Pelajaran 2019-2020, hal ini ditandai dengan peningkatan mutu guru dalam setiap siklus, yaitu siklus I 53,33\%, siklus II 86,67\%.
\end{abstract}

Keywords: Mutu sekolah, Kinerja guru, Pelatihan berkelanjutan

\section{PENDAHULUAN}

Pendidik merupakan faktor penting dalam meningkatkan kualitas pendidikan. Profesionalisme seorang pendidik berperan penting dalam mencapai mutu pendidikan yang lebih baik dengan berbagai proses pembelajaran kepada peserta didik. Pengembangan profesionalisme pendidik memberikan pengaruh dalam meningkatkan mutu pendidikan sebesar 32\% Bustomi dalam Aisyah (2019). Sehingga, sebagai upaya meningkatkan mutu pendidikan Indonesia harus dilakukan dengan meningkatkan mutu pendidik dalam hal ini adalah guru.

Pemerintah Indonesia berusaha eningkatkan kualitas pendidikan melalui penetapan standar atau kualifikasi khusus bagi guru seperti wajib memiliki kualifikasi akademik, kompetensi, sertifikat pendidik, sehat jasmani dan rohani, serta memiliki kemampuan untuk mewujudkan tujuan pendidikan nasional.

Berdasarkan Standar Pendidik dalam Peraturan Pemerintah No. 19 Tahun 2005 disebutkan bahwa " Pendidik harus memiliki kualifikasi akademik dan kompetensi sebagai agen pembelajaran, sehat jasmani dan rohani serta memilki kemampuan untuk mewujudkan tujuan pendidikan nasional".

Undang Undang Guru dan Dosen Nomor 14 Tahun 2005 tentang Guru dan Dosen dan PP Nomor 19 Tahun 2005 tentang Standar Nasional Pendidikan menyatakan kompetensi guru meliputi kompetensi kepribadian, pedagogik, profesional, dan sosial. Adapun yang dimaksud dengan keempat jenis kompetensi guru adalah: (1) Kompetensi Kepribadian merupakan kemampuan personal yang mencerminkan kepribadian yang mantap, stabil, dewasa, arif, dan berwibawa, menjadi teladan bagi peserta didik, dan berakhlak mulia; (2) Kompetensi Pedagogik, merupakan pemahaman terhadap peserta didik, perancangan dan pelaksanaan pembelajaran, evaluasi hasil belajar, dan pengembangan peserta didik untuk mengaktualisasikan berbagai potensi yang dimilikinya; (3) Kompetensi Profesional merupakan penguasaan materi pembelajaran secara luas dan mendalam, yang mencakup penguasaan materi kurikulum mata pelajaran di sekolah dan substansi keilmuan yang menaungi materinya, serta penguasaan terhadap stuktur dan metodologi keilmuannya; (4) Kompetensi Sosial merupakan kemampuan guru untuk 
berkomunikasi dan bergaul secara efektif dengan peserta didik, sesama pendidik, tenaga kependidikan, orangtua/wali peserta didik, dan masyarakat sekitar.

Bila keempat kompetensi tersebut di atas dapat dikuasai oleh seorang guru,maka mutu pendidikan akan meningkat. Namun kenyataan di lapangan masih banyak guru yang mengajar di kelas,terutama di tingkat sekolah dasar masih belum layak dalam melaksanakan pembelajaran di kelas.

Kelayakan mengajar guru tidak cukup hanya diukur berdasarkan pendidikan formal tetapi juga harus diukur berdasarkan bagaimana kemampuan guru dalam mengajar dan sesi penguasaan materi, menguasai, memilih dan menggunakan metode, media serta evaluasi pembelajaran. Sehubungan dengan hal itu, Jiyono (2006) menyimpulkan bahwa kemampuan guru SD dalam menguasai bahan pelajaran pada umumnya sangat menghawatirkan karena dari sampel guru SD yang diminta menunjukkan kemampuan menguasai bahan pelajaran $70 \%$ yang kurang menguasai bahan pelajaran, sedangkan hanya $30 \%$ yang menguasai bahan pelajaran.

Kondisi seperti itu diperparah dengan kurang optimalnya fungsi pengawasan kepala sekolah. Bila selama ini banyak pendapat menyatakan profesionalisme guru di Indonesia relatif rendah atau kurang memadai, hal itu merupakan akibat dari kurang kepengawasannya kepengawasan kepala sekolah.

Berdasarkan hasil observasi di SDN Lanta Barat dijumpai adanya kecenderungan melemahnya kinerja guru yaitu terjadinya guru yang membolos mengajar, guru yang masuk ke kelas yang tidak tepat waktu, guru mengajar tidak mempunyai persiapan mengajar, guru tidak punya absensi siswa, kemuadia adanya pelaksanaan supervisi yang dilakukan oleh kepala sekolah belum dilaksanakan dengan sebaik - baiknya kepada guru.

Berdasarkan Permasalah diatas maka penulis memandang perlu untuk melakukan penelitian tindakan dengan judul: Peningkatan Mutu Sekolah dengan Meningkatkan Kinerja Guru Melalui Pelatihan Berkelanjutan di SDN
Lanta Barat Tahun Pelajaran 2019-2020.

\section{METODE \\ Jenis Penelitian}

Penelitian ini adalah Penelitian Tindakan Sekolah. Penelitian ini dirancang dalam dua siklus. Setiap siklus meliputi perencanaan, tindakan, pengamatan, evaluasi serta refleksi (Azmin, 2019). Model dan penjelasan masing- masing tahap menurut Arikunto (2010) sebagai berikut:

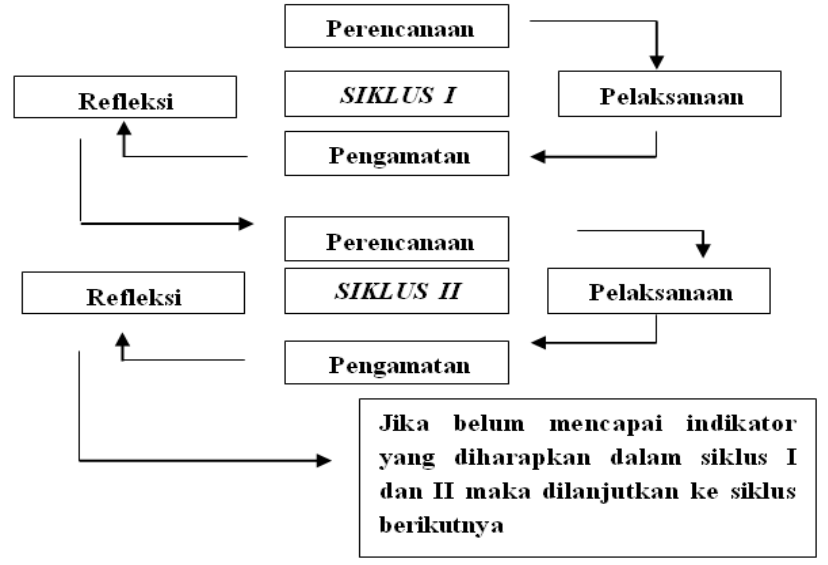

Gambar 1. Alur Penelitian Tindakan Sekolah

\section{Waktu dan Tempat Penelitian}

PTS ini dilakukan pada SDN Lanta Barat tahun Pelajaran 2019-2020. PTS dilakukan pada guru melalui pelatihan berkelanjutan untuk meningkatkan kinerja guru dalam upaya peningkatan capaian mutu sekolah di SDN Lanta Barat.

\section{Subyek Penelitian}

Subyek dalam penelitian ini adalah guru SDN Lanta Barat sebanyak 15 orang guru yang merupakan tempat peneliti bertugas menjadi kepala sekolah tahun pelajaran 20192020.

\section{Rencana Tindakan}

Penelitian ini dilakukan dengan metode penelitian tindakan kelas yang berlangsung selama 2 siklus. Masing-masing siklus terdiri dari tahapan perencanaan, pelaksanaan, observasi dan refleksi. Lama penelitian 4 pekan efektif dilaksanakan tahun pelajaran 2019-2020.

1. Rencana: adalah rencana tindakan apa yang akan dilakukan untuk memperbaiki, meningkatkan atau perubahan perilaku dan sikap sebagai solusi. 
2. Tindakan: adalah apa yang dilakukan oleh kepala sekolah sebagai upaya perbaikan, peningkatan atau perubahan yang diinginkan.

3. Observasi: adalah mengamati atas hasil atau dampak dari tindakan yang dilaksanakan atau dikenakan terhadap siswa.

4. Refleksi: adalah peneliti mengkaji, melihat, dan mempertimbangkan atas hasil atau dampak dari tindakan dari berbagai keriteria.

5. Revisi: adalah berdasarkan dari hasil refleksi ini,peneliti melakukan revisi terhadap rencana awal.

\section{Instrumen Penelitian}

Instrumen yang digunakan dalam penelitian ini adalah Lembar Observasi, dan angket. Adapun indikator yang akan diteliti adalah peningkatan mutu sekolah melalui peningkatan kinerja guru. Sedangkan variabel tindakan memiliki indikator sebagai berikut: Tingkat kualitas perencanaan, Kualitas perangkat observasi, Kualitas operasional tindakan, Kesesuaian perencanaan dengan tindakan, Kesesuaian materi pembinaan dan bimbingan yang diberikan, Tingkat efektifitas pelaksanaan pelatihan berkelanjutan, Kemampuan meningkatkan kinerja guru melalui pelatihan berkelanjutan.

\section{Teknik Analisis Data}

Dalam analisis data teknik yang digunakan adalah analisis secara deskriptif menghitung besarnya peningkatan mutu guru melalui pelatihan berkelanjutan dengan menggunakan prosentase.

Indikator keberhasilan apabila terjadi peningkatan kinerja guru mencapai $85 \%$ guru telah mencapai ketuntasan dengan nilai rata rata 75 .Jika peningkatan tersebut dapat dicapai pada tahap siklus 1 dan 2, maka siklus selanjutnya tidak akan dilaksanakan karena tindakan sekolah yang dilakukan sudah dinilai efektif sesuai dengan harapan dalam Manajemen Berbasis Sekolah

\section{HASIL DAN PEMBAHASAN Hasil Penelitian Hasil Siklus I}

Penelitian ini menggunakan pembinaan dengan menerapkan platihan berkelanjutan. Tujuan yang diharapkan pada pertemuan pertama dalam pelatihan berkelanjutan ini adalah untuk meningkatkan mutu guru dalam pembelajaran. Agar tercapai tujuan di atas, peneliti yang bertindak sebagai kepala sekolah melakukan langkah-langkah sebagai berikut :Menyusun instrumen pembinaan melalui pelatihan berkelanjutan, Menyusun Instrumen Monitoring, Sosialisasi kepada guru, Melaksanakan tindakan dalam pembinaan, Melakukan refleksi, Menyusun strategi pembinaan pada siklus ke dua berdasar refleksi siklus pertama, Melaksanakan pembinaan pada siklus kedua, Melakukan Observasi, Melakukan refleksi pada siklus kedua, Menyusun strategi pembinaan pada siklus ketiga berdasar refleksi siklus kedua, Melakukan Observasi, Menyusun laporan.

Pelaksanaan tindakan dalam penelitian dilakukan 2 siklus yang terdiri dari empat kali pertemuan. Waktu yang digunakan setiap kali pertemuan adalah 2 x 60 menit. Penelitian tindakan sekolah dilaksanakan sesuai dengan prosedur rencana pembinaan dan skenario pembelajaran.

\section{Tahap Perencanaan}

Pada tahap ini peneliti mempersiapkan perangkat pembinaan yang terdiri dari rencana pembinaan 1, Instrumen 1, Evaluasi 1 dan alat-alat pembinaan yang mendukung. Selain itu juga dipersiapkan lembar observasi pengolaan pembelajaran.

2. Tahap Kegiatan dan Pelaksanaan

Pelaksanaan kegiatan pembinaan untuk siklus I dilaksanakan pada 15 orang guru. Dalam hal ini peneliti bertindak sebagai kepala sekolah. Adapun proses pembinaan mengacu pada rencana pelajaran yang telah dipersiapkan.

Pengamatan dilaksanakan bersamaan dengan pelaksaaan belajar mengajar. Pada akhir proses pembinaan, guru diberi tes formatif I dengan tujuan untuk mengetahui tingkat mutu guru dalam proses belajar 
mengajar yang telah dilakukan. Adapun data hasil penelitian pada siklus I. adalah seperti pada tabel berikut :

Tabel 1 Nilai Tes Pembinaan Kepala Sekolah melalui Pelatihan Berkelanjutan Siklus I

\begin{tabular}{|l|c|}
\hline \multicolumn{1}{|c|}{ Uraian } & Nilai \\
\hline Total Skor & $\mathbf{1 0 5 0}$ \\
\hline Nilai Terendah & $\mathbf{6 0}$ \\
\hline Nilai Tertinggi & $\mathbf{8 0}$ \\
\hline Tuntas & $\mathbf{8}$ \\
\hline BelumTuntas & $\mathbf{7}$ \\
\hline Ketuntasan & $\mathbf{5 3 , 3 3 \%}$ \\
\hline
\end{tabular}

Dari tabel di atas dapat dijelaskan bahwa dengan menerapkan pembinaan melalui pelatihan berkelanjutan diperoleh nilai kinerja guru adalah $53,33 \%$ atau ada 8 orang guru dari 15 orang sudah meningkat mutunya dalam proses belajar mengajar. Hasil tersebut menunjukkan bahwa pada siklus I secara kelompok guru belum meningkat mutunya, hanya sebesar 53,33\% lebih kecil dari persentase ketuntasan yang dikehendaki yaitu sebesar $\geq 85 \%$. Hal ini disebabkan karena guru masih merasa baru dan belum mengerti apa yang dimaksudkan. Sehingga mereka belum banyak mengerti tentang pelatihan berkelanjutan.

3. Refleksi

Dalam pelaksanaan kegiatan belajar mengajar diperoleh informasi dari hasil pengamatan sebagai berikut:

(1) Kepala sekolah kurang baik dalam memotivasi guru dan dalam menyampaikan tujuan pembinaan.

(2) Kepala sekolah kurang baik dalam pengelolaan waktu

(3) Guru kurang begitu antusias selama pembelajaran berlangsung.

4. Revisi Rancangan

Pelaksanaan kegiatan pembinaan pada siklus I ini masih terdapat kekurangan, sehingga perlu adanya revisi untuk dilakukan pada siklus berikutnya.

1) Kepala sekolah perlu lebih terampil dalam memotivasi guru dan lebih jelas dalam menyampaikan tujuan pembinaan. Di mana guru diajak untuk terlibat langsung dalam setiap kegiatan yang akan dilakukan.
2) Kepala sekolah perlu mendistribusikan waktu secara baik dengan menambahkan informasi-informasi yang dirasa perlu dan memberi catatan

3) Kepala sekolah harus lebih terampil dan bersemangat dalam memotivasi guru sehingga guru bisa lebih antusias.

\section{Hasil Siklus II}

1. Tahap perencanaan

Pada tahap ini peneliti mempersiapkan perangkat pembinaan yang terdiri dari rencana pembinaan 2, soal tes formatif II dan alat-alat pembinaan yang mendukung.

2. Tahap kegiatan dan pelaksanaan

Pelaksanaan kegiatan pembinaan untuk siklus II dilaksanakan di SDN Lanta Barat tahun pelajaran 2019-2020. Peneliti bertindak sebagai kepala sekolah. Adapun proses pembinaan mengacu pada rencana pembinaan dengan memperhatikan revisi pada siklus I, sehingga kesalahan atau kekurangan pada siklus I tidak terulang lagi pada siklus II. Pengamatan (observasi) dilaksanakan bersamaan dengan pelaksanaan belajar mengajar.

Pada akhir proses pembinaan,guru diberi tes formatif II dengan tujuan untuk mengetahui peningkatan mutu guru dalam proses pembinaan yang telah dilakukan. Instrumen yang digunakan adalah tes formatif II. Adapun data hasil penelitian pada siklus II adalah sebagai berikut.

\section{Tabel 2. Nilai Tes Pembinaan Kepala Sekolah melalui Pelatihan Berkelanjutan Siklus II}

\begin{tabular}{|l|c|}
\hline \multicolumn{1}{|c|}{ Uraian } & Nilai \\
\hline Total Skor & $\mathbf{1 2 5 0}$ \\
\hline Nilai Terendah & $\mathbf{7 0}$ \\
\hline Nilai Tertinggi & $\mathbf{9 5}$ \\
\hline Tuntas & $\mathbf{1 3}$ \\
\hline BelumTuntas & $\mathbf{2}$ \\
\hline Ketuntasan & $\mathbf{8 6 , 6 7 \%}$ \\
\hline
\end{tabular}

Dari tabel di atas diperoleh nilai peningkatan mutu guru adalah $86,67 \%$ atau ada 13 orang guru dari 15 orang guru sudah meningkat mutunya dalam proses belajar mengajar. Hasil ini menunjukkan bahwa pada 
siklus II ini ketuntasan belajar secara klasikal telah mengalami peningkatan lebih baik dari siklus I. Adanya peningkatan mutu guru ini karena setelah kepala sekolah menginformasikan bahwa setiap akhir pembinaan akan selalu diadakan tes sehingga pada pertemuan berikutnya guru lebih termotivasi meningkatkan mutunya dalam proses pembelajaran. oleh adanya peningkatan kemampuan kepala sekoah dalam melakukan pembinaan melalui pelatihan berkelanjutan sehingga guru menjadi lebih terbiasa dengan pembinaan seperti ini sehingga guru lebih mudah dalam memahami pembinaan yang telah diberikan oleh kepala sekolah. Di samping itu ketuntasan ini juga dipengaruhi oleh kerja sama dari guru yang telah menguasai proses pembelajaran untuk membimbing guru yang belum menguasainya melalui pelatihan berkelanutan oleh kepala sekolah.

\section{Refleksi}

Dalam pelaksanaan kegiatan pembinaan diperoleh informasi dari hasil pengamatan sebagai berikut: Memotivasi guru, Membimbing guru merumuskan kesimpulan/menemukan konsep, Pengelolaan waktu

\section{Revisi Pelaksanaaan}

Dari data-data yang telah diperoleh dapat duraikan sebagai berikut :

(1) Selama proses pembinaan kepala sekolah telah melaksanakan semua pembinaan dengan baik. Meskipun ada beberapa aspek yang belum sempurna, tetapi persentase pelaksanaannya untuk masingmasing aspek cukup besar.

(2) Berdasarkan data hasil pengamatan diketahui bahwa guru aktif selama proses belajar berlangsung.

(3) Kekurangan pada siklus-siklus sebelumnya sudah mengalami perbaikan dan peningkatan sehingga menjadi lebih baik.

(4) Hasil pembinaan melalui pelatihan berkelanjutan pada siklus II mencapai ketuntasan.

Maka tidak diperlukan revisi terlalu banyak, tetapi yang perlu diperhatikan untuk tindakah selanjutnya adalah memaksimalkan dan mempertahankan apa yang telah ada dengan tujuan agar pada pelaksanaan proses belajar mengajar selanjutnya pembinaan yang dilakukan kepala sekolah melalui pelatihan berkelanjutan dapat meningkatkan mutu guru dalam proses belajar mengajar sehingga tujuan pembelajaran dapat tercapai.

\section{Pembahasan}

Hasil penelitian ini menunjukkan bahwa penerapan pelatihan berkelanjutan kepala sekolah memiliki dampak positif dalam meningkatkan mutu guru, hal ini dapat dilihat dari semakin mantapnya pemahaman guru dari pembinaan yang diberikan oleh kepala sekolah dengan nilai ketuntasan pembinaan meningkat dari siklus I 53,33\% menjadi $86,67 \%$ pada siklus II, sehingga pada siklus II ketuntasan pembinaan guru secara kelompok telah tercapai. Sementar umtuk aktivitas guru dalam pembinaan yang dilakukan kepala sekolah melalui pelatihan berkelanjutan dalam setiap siklus mengalami peningkatan. Hal ini berdampak positif terhadap peningkatan kinerja guru yaitu dapat ditunjukkan dengan meningkatnya nilai ratarata yang dicapai guru pada setiap siklus yang terus mengalami peningkatan.

Aktivitas guru dan kepala sekolah dalam proses pembinaan melalui pelatihan berkelanjutan yang paling dominan adalah bekerja dengan menggunakan alat, mendengarkan penjelasan kepala sekolah, dan diskusi antar guru antara guru dan kepala sekolah. Jadi dapat dikatakan bahwa aktivitas guru dapat dikategorikan aktif.

Berdasarkan manajemen berbasis sekolah dikatakan tuntas apabila guru telah mencapai nilai standar ideal 75 mencapai $\geq 85$ $\%$. Pada siklus II mencapai melebihi target yang ditetapkan dalam MBS yaitu mencapai 86,67 \%. Dengan demikian maka dapat disimpulkan bahwa ada peningkatan mutu sekolah di SDN Lanta Barat dengan meningkatkan Kinerja Guru Melalui Pelatihan Berkelanjutan Tahun Pelajaran 2019-2020.

\section{KESIMPULAN}

Berdasarkan hasil analisis data dan pembahasan yang telah dilakukan dapat 
disimpulkan bahwa: ada peningkatan mutu sekolah di SDN Lanta Barat dengan meningkatkan Kinerja Guru Melalui Pelatihan Berkelanjutan Tahun Pelajaran 2019-2020, hal ini ditandai dengan peningkatan mutu guru dalam setiap siklus, yaitu siklus I $53,33 \%$, siklus II $86,67 \%$.

\section{DAFTAR PUSTAKA}

Aisiyah. 2019. Peningkatan Capaian Mutu Sekolah dengan Meningkatkan Kinerja Guru Dalam Merencanakan dan Melaksanakan Proses Pembelajaran Melalui Pelatihan Berkelanjutan di SD Negeri Mojosari 01. urnal Mitra Pendidikan (JMP Online). Vol. 3 No. 7 Juli (2019) 1022 - 1032.

Arikunto. S. 2010. Prosedur Penilitian Suatu Pendekatan Praktek. Jakarta:Renika Cipta.

Azmin, N., \& Nasir, M. (2019). PENERAPAN MODEL PEMBELAJARAN 5E UNTUK MENINGKATKAN

KETERAMPILAN PROSES SAINS DAN SIKAP ILMIAH SISWA KELAS VIII SMP NEGRI 6 KOTA BIMA. ORYZA Jurnal Pendidikan Biologi, 8(2), 40-46.

Depdiknas RI,2005,Undang undang No 15 Tentang Guru dan Dosen.Jakarta : Depdiknas.

\begin{tabular}{l}
,2006.Peraturan Pemerintah No \\
\hline 19 Tentang Standar Isi \\
Pendidikan.Jakarta : BSNP.
\end{tabular}

Jiyono. 2006. Cara Mengukur Mutu Pendidikan. Analisis Pendidikan 1 dan 2. 